\title{
Pemanfaatan Rawa Pasang Surut Untuk Tambak Ikan Bandeng
}

\author{
Bayu Aji Girawan ${ }^{1 *}$, Sugeng Dwi Riyanto ${ }^{2}$, Khoeruddin Wittriansyah ${ }^{3}$ \\ ${ }^{1}$ Program Studi Teknik Mesin, Politeknik Negeri Cilacap, Indonesia \\ ${ }^{2}$ Program Studi Teknik Elektronika, Politeknik Negeri Cilacap, Indonesia \\ ${ }^{3}$ Program Studi Teknik Mesin Perikanan, Politeknik Negeri Cilacap, Indonesia \\ Email: ${ }^{1}$ bayuajigirawan@gmail.com, ${ }^{2}$ sugengdr82@gmail.com, ${ }^{3}$ khoepapua@gmail.com
}

\section{INFORMASI ARTIKEL}

\section{Data artikel:}

Naskah masuk, 04 Februari 2020

Direvisi, 30 April 2020

Diterima, 19 Agustus 2020

\section{Kata Kunci:}

Rawa pasang-surut

Budidaya bandeng

Kolam pembilasan

\begin{abstract}
ABSTRAK
Abstract- Tritih Lor is a village at Cilacap that consists of swaps that are formed by ocean tides. Our partner as a fish farmer group at Tritih Lor has utilized the swamp for milkfish cultivation to use a traditional system. There are some troubles on their business like the production is too low because they use a traditional system that relies on natural food from a relic carried away by the tides. Another problem that the fish are gone along the tide when the fish pond breaks. To solve that problem, we use a method of repairing the fish pond, install and arrangement of water intake and aeration systems, installation fence around the fish pond, installation of solar panels, pond fertilization, stocking the pond, and harvesting. The result of this activity is an increase in productivity and a decrease in fish mortality. This semi-intensive tidal swamp aquaculture pond can answer the previous problems of traditional cultivation. This activity also can create more technological-based cultivators, make a better income, and increase the usability of the unused land.
\end{abstract}

Abstrak- Desa Tritih Lor, Kecamatan Jeruklegi, Kabupaten Cilacap merupakan daerah rawa pasang-surut. Mitra yang merupakan kelompok pembudidaya ikan (pokdakan) yang berada di desa Tritih Lor, telah memanfaatkan daerah rawa pasang-surut tersebut untuk budidaya ikan bandeng dengan sistem kolam pasangsurut secara tradisional. Mitra menjalankan budidaya tersebut dengan sistem tradisional sehingga terdapat beberapa kendala. Kendala tersebut antara lain berupa rendahnya tingkat produksi akibat padat tebar benih ikan bandeng, dan pakan yang hanya mengandalkan secara alami berupa renik yang terbawa oleh air pasang. Selain itu, permasalahan lainnya adalah hilangnya ikan yang ditebar jika terjadi kerusakan pada tanggul/pematang kolam. Hal ini disebabkan karena tinggi pematang yang masih berada di bawah permukaan air ketika pasang tinggi terjadi. Tahapantahapan dilakukan dalam menyelesaikan permasalahan mitra adalah berupa perbaikan dan penguatan tanggul kolam, melakukan pemasangan dan pengaturan sistem pemasukan air dan aerasi, pemasangan pagar waring keliling, instalasi panel surya, pemupukan kolam, penaburan benih ikan, dan pemanenan. Hasil dari kegiatan ini adalah terjadinya peningkatan produktivitas dan menurunnya tingkat kematian 
ikan. Kolam budidaya rawa pasang surut semi intensif ini dapat menjawab permasalahan mitra sebelumnya yang menjalankan budidaya dengan cara tradisional.

\section{Korespondensi:}

\section{Bayu Aji Girawan}

Program Studi Teknik Mesin, Politeknik Negeri Cilacap

Jl. Dr. Soetomo No.1 Karangcengis, Sidakaya Cilacap, Indonesia

\section{PENDAHULUAN}

Desa Tritih Lor, Kecamatan Jeruklegi merupakan salah satu desa di Kabupaten Cilacap yang rawa pasang surut. Penduduk setempat yang merupakan mitra pengabdian ini, memanfaatkan rawa pasang-surut tersebut sebagai tambak pembesaran ikan bandeng secara tradisional. Pada saat pasang, daerah rawa akan dipenuhi oleh air laut yang masuk dari daerah teluk penyu sampai ke rawa. Ketinggian air pasang bervariasi tergantung pada musim, dari mulai yang terendah adalah 0,75 sampai dengan yang tertinggi 2,5 meter. Pada saat pasang, volume air dari laut akan masuk ke rawa dengan ketinggian tertentu. Kondisi ini akan bertahan selama 30 sampai 60 menit, sebelum akhirnya surut secara perlahan hingga kondisi rawa tidak berair. Kejadian pasang-surut rawa akan terjadi sebanyak 2 kali siklus selama satu hari mengikuti ritme pasang-surut air laut. Pokdakan Rukun Mulya telah memanfaatkan rawa pasang-surut untuk budidaya ikan bandeng. Budidaya tersebut dilakukan secara tradisional sehingga terdapat beberapa kendala berupa tingkat produktivitas yang rendah dan ikan yang rentan hilang jika terjadi kerusakan pada tanggul.

Rawa pasang surut tersebut merupakan area dari segara anakan yang kaya akan fitoplankton. Kandungan fitoplankton tersebut telah dianalisa menggunakan metode lackey drop micro-transect counting dan ditampilkan dalam bentuk peta menggunakan software Arc Gis 10.2. Dari hasil penelitian menunjukkan bahwa komposisi fitoplankton secara berturutturut dari yang terbanyak didominasi oleh divisi chrysophyita, chlorophyta, cyanophyta, pyrophyta dan euglenophyta (Dewi et al., 2019).
Studi tentang jenis-jenis fitoplankton dengan kualitas omega-3 tinggi telah dilakukan untuk mengetahui kadar omega-3 dari plankton yang terdapat pada perariran tambak tradisional ikan bandeng. Komposisi pada perairan tambak tradisional ikan bandeng terdiri dari 4 divisi fitoplankton yaitu Chlorophyta, Chrysophyta, Cyanophyta, dan Euglenophyta. Dalam studi ini ditentukan lima jenis plankton untuk diuji kandungan asam lemak omega-3 dengan menggunakan metode gas kromatografi (GCMS) yaitu: Chaetoceros sp, Tetraselmis sp, Nitzchia, Chlorella dan Spirulina. Hasil uji GCMS dari beberapa jenis isolat plankton asam lemak omega-3 dalam Chaetoceros sp, paling tinggi dibandingkan Tetraselmis sp, Nitzchia, Chlorella dan Spirulina (Herawati, 2019).

Ikan bandeng menjadi pilihan yang baik dalam rangka pemanfaatan lahan tidur di daerah rawa pasang-surut yang notabene mempunyai karakteristik air payau karena ikan bandeng mempunyai keunggulan: merupakan ikan asli Indonesia yang mempunyai toleransi sangat besar terhadap salinitas lingkungannya yaitu antara 8-105 ppt, sumber protein yang potensial bagi pemenuhan gizi masyarakat, dan mempunyai kualitas rasa daging yang enak. Selain itu, lingkungan rawa pasang-surut mempunyai kandungan oksigen terlarut dalam terendah sekitar $1,1 \mathrm{mg} /$ liter yang notabene masih dapat ditolerir oleh ikan bandeng. Kandungan oksigen terlarut ini semakin lama semakin rendah seiring dengan bertambahnya masa pemeliharaan (Hendrajat \& Mangampa, 2014).

Rawa juga merupakan tempat tumbuhnya mangrove. Keberadaan mangrove ini menunjang keberlanjutan siklus hidup dari 
ekosistem disepanjang aliran rawa pasangsurut. Mangrove berperan sebagai penampung akhir bagi limbah dari industri di perkotaan dan perkampungan hulu yang terbawa aliran. Area hutan mangrove bahkan mempunyai kemampuan mengakumulasi logam berat yang terdapat dalam ekosistem tempat tumbuhnya (Kariada \& Irsadi, 2014).

Peningkatan kualitas nutrisi bandeng diperlukan untuk memperoleh bahan baku yang tidak hanya banyak tetapi juga bernutrisi. Penambahan probiotik ke dalam pakan bandeng dapat meningkatkan efisiensi pakan agar pakan lebih mudah dicerna dan enzim dapat bekerja lebih efektif. Hasil penelitian menunjukkan bahwa pakan bandeng komersil dengan kandungan protein $30 \%$ dan probiotik dengan komposisi jamur Saccharomyces cerevisiae, Aspergillus oryzae, bakteri Lactobacillus acidophilus, Bacillus subtilis, Rhodopseudomonas, Actinomycetes dan Nitrobacter memberikan nilai RGR (1.958 $\pm 0.02 \%$ /hari), nilai $\quad$ EPP $(78.333 \pm 0.745 \%)$, kandungan protein $(25.794 \pm 0.600 \%)$ lebih tinggi dan FCR (1.321 \pm 0.030$)$ yang lebih baik dari perlakuan tanpa penggunaan probiotik dalam pakan bandeng (Diana Chilmawati, Fronthea Swastawati, Ima Wijayanti, Ambaryanto, 2018). Pengaruh kuantitas pemberian probiotik dan pupuk ini juga berpengaruh terhadap jumlah pertumbuhan ikan bandeng yang berimbas pada pendapatan. Sistem semi intensif dengan pemberian pupuk dan probiotik yang lebih banyak akan meningkatkan produktivitias dengan signifikan (Prawiro et al., 2020).

Jika dilihat dari kelayakan, berbagai penelitian tentang kelayakan usaha budidaya ikan bandeng telah banyak dilakukan, diantaranya adalah sebuah studi yang dilakukan di Kabupaten Indramayu. Berdasarkan hasil penelitian, usaha ini layak untuk dijalakankan, namun terdapat beberapa kendala berupa benih yang kurang berkualitas, kondisi saluran irigasi yang buruk, harga pakan yang mahal, serta konstruksi kolam yang belum memenuhi cara budidaya ikan yang baik (Triyanti \& Hikmah, 2015). Studi juga dilakukan untuk menganalisis pendapatan petani tambak ikan bandeng di Kecamatan Woha, Kabupaten Bima. Dari hasil analisis ternyata pendapatan yang bisa dihasilkan dari tambak ikan bandeng sebesar Rp. 31.015.15/Ha. Faktor yang mempengaruhi pendapatan tersebut adalah berupa produksi, benih, luas lahan, HKO, pengalaman dan pendidikan (Nurfadillah et al., 2020). Sedangkan di Kecamatan Pasir Sakti, Kabupaten Lampung Timur, pendapatan dari petani dapat berkisar Rp. 22.809.890/Ha namun kendala yang dihadapi berupa pemsaran yang belum efisien (Putri et al., 2019). Permasalahan-permasalah yang timbul dari para petani tambak tersebut pada dasarnya adalah sesuainya konstruksi tambak dan prasarana pendukung yang kurang memadai sehingga perlu adanya proses alih teknologi yang terdiri atas kegiatan inti berupa pelaksanaan budidaya dengan melibatkan kelompok pembudidaya serta kegiatan pendukung berupa penguatan infrastruktur, penguatan kapasitas SDM (Firdaus et al., 2016). Namun jika dilihat dari sisi ekologi, adanya tambak akan menyebabkan pencemaran lingkungan karena adanya penggunaan pakan buatan sehingga diperlukan penyeimbang ekologi melalui rehabilitasi pada ekosistem mangrove (Mulyawan et al., 2017).

Berdasarkan literatur review yang telah dilakukan, maka pemanfaatan rawa pasangsurut untuk tambak ikan bandeng sangat menjanjikan karena daerah ini sangat kaya akan fitoplankton yang bermanfaat bagi pertumbuhan ikan bandeng. Produktivitas dapat ditingkatkan melalui pola pengelolaan tambak semi intensif.

Target luaran dari kegiatan ini nantinya adalah berupa peningkatan hasil produksi melalui pengelolaan tambak semi intensif.

\section{METODE PELAKSANAAN}

Kegiatan Pengabdian kepada Masyarakat di Desa Tritih Lor dilaksanakan melalui 
beberapa tahapan. Tahapan tersebut dapat dilihat pada gambar 1.

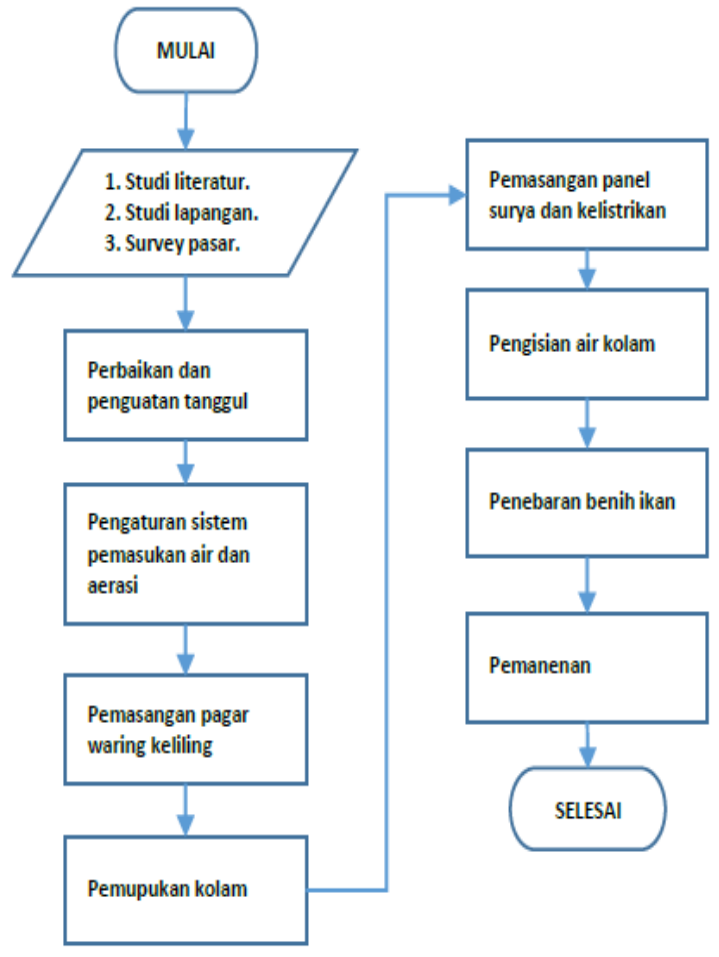

Gambar 1. Metode dan Tahapan Pelaksanaan

Tahapan tersebut yaitu:

1. Perbaikan dan penguatan tanggul.

Pada tahap ini, tanggul kolam dibuat lebih kokoh. Setelah perbaikan tanggul selesai dilakukan, selanjutnya dilakukan penanaman pohon bakau mengelilingi lokasi kolam, yang nantinya akan berfungsi sebagai penguat tanggul.

2. Pemasangan dan pengaturan sistem pemasukan air dan aerasi.

Pada tahap ini akan dilakukan desain, pemasangan serta pengaturan sistem pemasukan air.

3. Pemasangan pagar waring keliling.

Pada tahap ini akan dilakukan pemasangan waring di dalam kolam. Waring dipasang dan diikat pada bambu yang dipasang berkeliling.

4. Instalasi panel surya.

Pada tahap ini akan dilakukan pemasangan panel surya sebagai sumber energi listrik untuk sistem aerasi.

5. Pemupukan kolam.
Setelah semuanya selesai dikerjakan, tahap selanjutnya adalah pemupukan dasar kolam.

6. Pengisian air kolam.

Pada tahap ini, kolam siap digunakan dan diisi dengan air.

7. Penebaran benih.

Pada tahap ini, benih bandeng siap untuk dimasukkan ke dalam kolam.

8. Pemanenan.

Pada tahap ini dilakukan pemanenan ikan hasil budidaya kolam yang telah dibuat. Tim PkM akan mengamati kegiatan dan hasil panen untuk menganalisa perbedaan hasil panen kolam dengan sistem aerasi,pembilasan dengan kolam tradisional sebelum diadakan PkM.

Hasil dari kegiatan ini dievaluasi dengan membandingkan berat produksi yang dihasilkan sebelum adanya kegiatan ini dengan setelahnya.

\section{HASIL DAN PEMBAHASAN}

Identifikasi permasalahan yang terjadi pada mitra berupa tingkat produksi yang rendah dan keamanan ikan ketika terjadi kerusakan tanggul.

Permasalahan keamanan ikan salah satunya diatasi melalui perbaikan tanggul/ pematang.

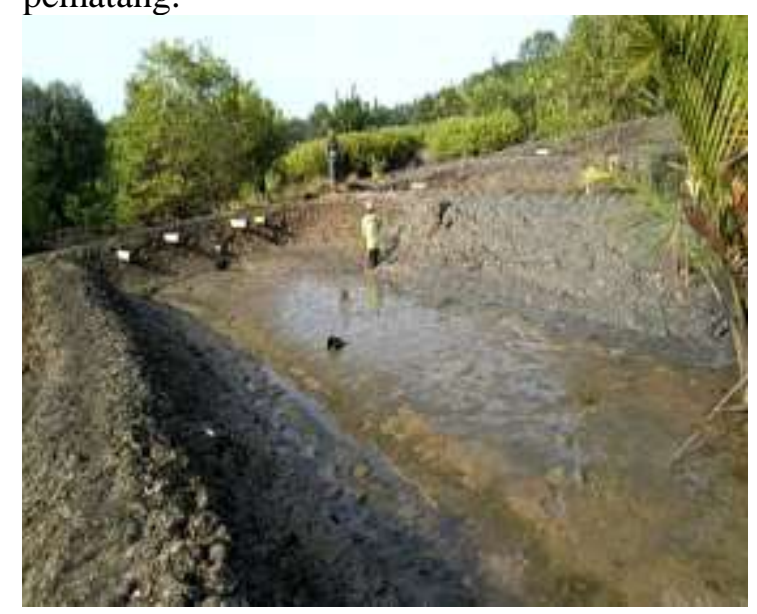

Gambar 2. Perbaikan tanggul/pematang

Proses perbaikan tanggul dilakukan dengan cara menaikkan lumpur di sekitar kolam. Hal ini karena proses ini dapat menekan pembiayaan jika dibandingkan dengan pengurugan menggunakan tanah mengingat letak kolam ada di tengah rawa. 


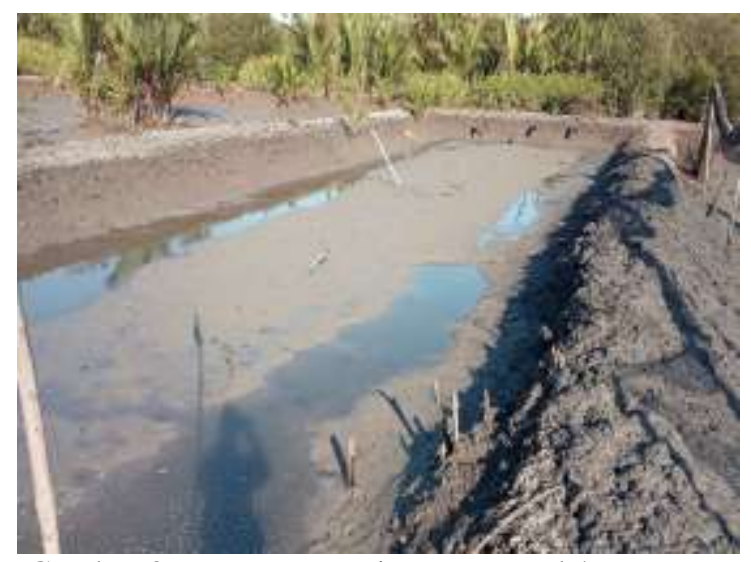

Gambar 3. Proses pengeringan tanggul / pematang

Setelah tanggul diperbaiki, tahap selanjutnya adalah pemagaran menggunakan waring pada bagian dalam kolam.

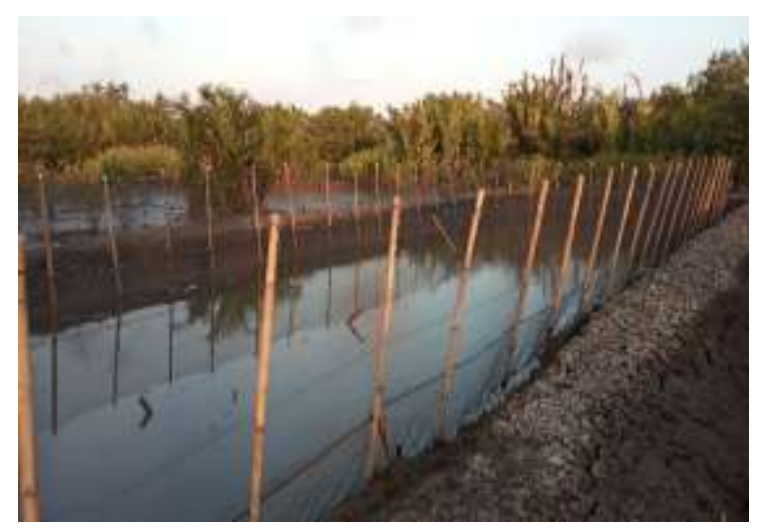

Gambar 4. Pemagaran waring di dalam kolam

Dengan melakukan pemagaran di dalam kolam, maka jika suatu saat kolam mengalami kebocoran dikarenakan kerusakan tanggul, maka ikan tidak keluar dari dalam kolam.

Untuk permasalahan rendahnya tingkat produksi, dilakukan pemasangan sistem pemasukan air yang dimodifikasi sedemikian rupa sehingga ketika air laut pasang akan terjadi proses pembilasan di dalam kolam.

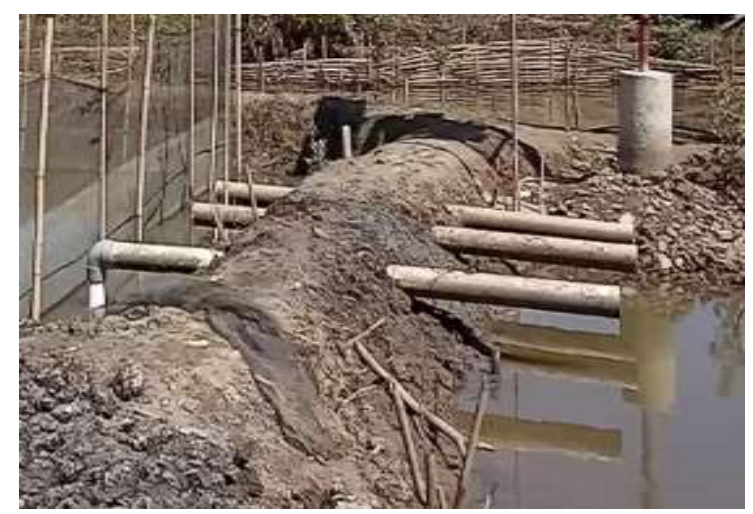

Gambar 5. Sistem pemasukan air model pembilasan
Model pembilasan tersebut dimaksudkan untuk membuang residu yang timbul dengan adanya penambahan pakan buatan. Selain modifikasi sistem pemasukan air, sistem aerasi bertenaga surya dipasang untuk memperkaya kandungan oksigen terlarut di dalam air. Hal ini akan meminimalisir kematian ikan karena rendahnya kandungan oksigen di dalam air karena adanya residu dari pemberian pakan buatan

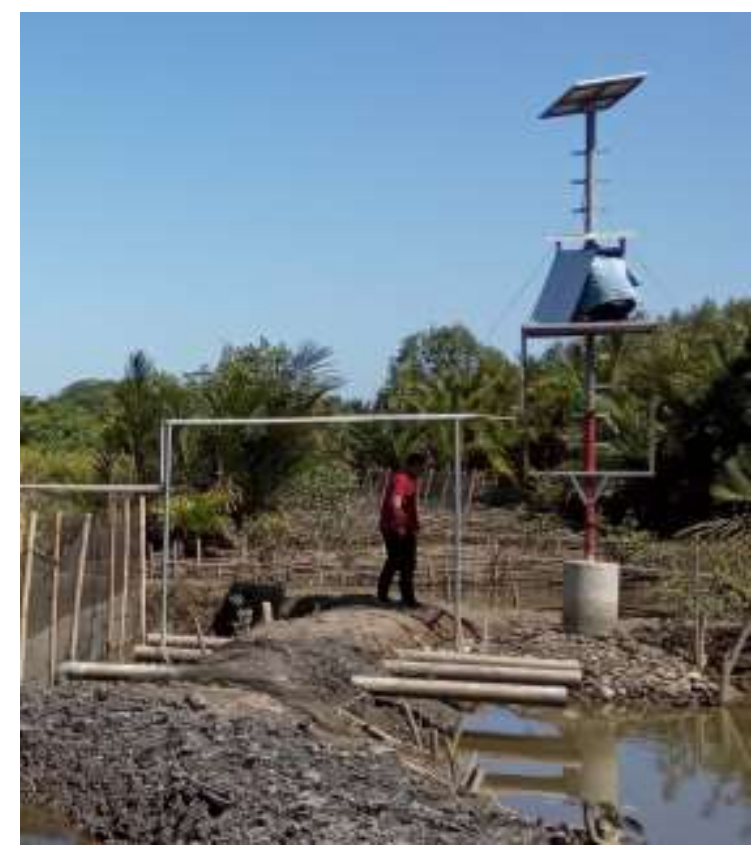

Gambar 6. Pemasangan panel surya dan sistem aerasi.

Dari tahapan yang sudah dilakukan, hasil produksi ikan pada saat panen sebelum dan setelah diterapkan sistem semi intensif ini dapat dilihat pada Tabel 1.

Tabel 1.Hasil Panen

\begin{tabular}{llll}
\hline No. & \multicolumn{1}{c}{ Kriteria } & Sebelum & Setelah \\
\hline 1. & Waktu & 4 bulan & 4 bulan \\
& pemeliharaan & & \\
2. & Jumlah benih & 6.000 & 6.000 \\
& ekor & ekor \\
3. & Berat ikan total & $1.105 \mathrm{~kg}$ & $1.200 \mathrm{~kg}$ \\
4. & $\begin{array}{l}\text { Jumlah ikan } \\
\text { dalam 1 kg ekor }\end{array}$ & 3 ekor \\
5 & Pelet & $400 \mathrm{~kg}$ & $400 \mathrm{~kg}$ \\
\hline
\end{tabular}

Dengan waktu, jumlah bibit dan pakan yang sama, sistem semi intensif ini dapat meningkatkan produktivitas sebesar $7.9 \%$ per $\mathrm{Ha}$, dengan berat ikan dalam $1 \mathrm{~kg}$ sebanyak 3 ekor. Jadi terdapat peningkatan secara kualitas 
maupun kuantitas dari hasil panen ketika sistem budidaya dilakukan peningkatan secara semi intensif. Faktor tersebut bisa jadi karena menurunnya tingkat kematian bandeng.

\section{KESIMPULAN}

Kesimpulan dari kegiatan Pengabdian kepada Masyarakat (PKM) di Desa Tritih Lor oleh ini adalah terwujudnya kolam tambak pada rawa pasang surut dengan sistem pembilasan serta menggunakan teknologi sistem aerasi dan pembilasan memberikan peningkatan produktivitas secara kuantitatif maupun kualitatif.

Saran yang perlu dilakukan untuk peningkatan produktivitas lebih lanjut adalah dengan melakukan pengelolaan yang lebih intensif sehinga padat tebar ikan bandeng dapat ditingkatkan sehingga produktivitas juga akan meningkat..

\section{UCAPAN TERIMA KASIH}

Penulis mengucapkan terimakasih atas terlaksananya kegiatan Pengabdian kepada Masyarakat ini dengan baik, kepada Kemenristekdikti atas pendanaan Program Kemitraan DRPM Tahun Anggaran 20182019, Politeknik Negeri Cilacap khususnya Jurusan Teknik Mesin dan Pusat Penelitian dan Pengabdian kepada Masyarakat (PPM), atas segala fasilitas yang digunakan dalam kegiatan pengabdian kepada masyarakat ini, dan Pokdakan Rukun Mulya yang telah kooperatif hingga kegiatan ini terlaksana dengan baik hingga paripurna.

\section{DAFTAR PUSTAKA}

Dewi, R., Zainuri, M., Anggoro, S., \& Winanto, T. (2019). A Spatio-Temporal Analysis on the Composition and Abundance of Phytoplankton in Segara Anakan Lagoon Area. Earth and Environmental Science, 406(1). https://doi.org/10.1088/1755-

1315/406/1/012028

Diana Chilmawati, Fronthea Swastawati, Ima Wijayanti, Ambaryanto, B. C. (2018). Penggunaan Probiotik Guna Peningkatan Pertumbuhan, Efisiensi Pakan, Tingkat Kelulushidupan dan Nilai Nutrisi Ikan Bandeng (Chanos chanos). Saintek Perikanan, 13(2), 119-125.

Firdaus, M., Indriana, L. F., Dwiono, S. A. P., \& Munandar, H. (2016). Konsep dan
Proses Alih Teknologi Budidaya Terpadu Teripang Pasir, Bandeng dan Rumput Laut. Seminar Nasional Technopreneurship Dan Alih Teknologi, February 2017, 51-63.

Hendrajat, E. A., \& Mangampa, M. (2014). Fluktuasi Oksigen Terlarut Harian pada Tambak Polikultur Udang Windu (Panaeus monodon), Rumput Laut (Gracilaria sp.), dan Ikan Bandeng (Chanos chanos). Prosiding Forum Inovasi Tenologi Akuakultur 2014, 2, 311-318.

Herawati, E. Y. (2019). Identifikasi Jenis-jenis Phytoplankton pada Tambak Bandeng dengan Kualitas Omega-3 Tinggi. Journal of Fisheries and Marine Research, 3(2), 258-262.

Kariada, N., \& Irsadi, A. (2014). Peranan Mangrove Sebagai Biofilter Pencemaran Air Wilayah Tambak Bandeng Tapak, Semarang. Jurnal Manusia Dan Lingkungan, 21(2), 188-194. https://doi.org/10.22146/jml.18543

Mulyawan, I., Zamroni, A., \& Priyatna, F. N. (2017). Kajian Keberlanjutan Pengelolaan Budidaya Ikan Bandeng Di Gresik. Jurnal Kebijakan Sosial Ekonomi Kelautan Dan Perikanan, 6(1), 25. https://doi.org/10.15578/jksekp.v6i1.260 7

Nurfadillah, Hidayati, A., \& Maryati, S. (2020). Analisis Pendapatan Petani Tambak Ikan Bandeng di Kecamatan Woha Kabupaten Bima. AGROTEKSOS: Agronomi Teknologi Dan Sosial Ekonomi Pertanian, 29(3), 112. https://doi.org/10.29303/agroteksos.v29i3 .203

Prawiro, M. K., Afendi, F. M., Setiawan, M. B., Heriwibowo, D., Zulkieflimansyah, \& Witarto, A. B. (2020). Manajemen Pengelolaan Tambak Ikan Bandeng Desa Labuhan Kuris Kecamatan Lape Kabupaten Sumbawa. Distribusi, 8(1), 93-104.

https://doi.org/10.29303/distribusi.v8i1.1 12

Putri, A., Widjaya, S., \& Kasymir, E. (2019). Pendapatan Usahatani Polikultur Udang Windu-Ikan Bandeng Dan Efisiensi Pemasaran Ikan Bandeng Di Kecamatan Pasir Sakti Kabupaten Lampung Timur. Jurnal Ilmu-Ilmu Agribisnis, 6(3), 242- 
Madani : Indonesian Journal Of Civil Society

Vol. 2, No. 2, Agustus 2020, pp. 08-14

248.

https://doi.org/10.23960/jiia.v6i3.242248

Triyanti, R., \& Hikmah. (2015). Analisis Kelayakan Usaha Budidaya Udang dan
p-ISSN: 2686-2301

e-ISSN: 2686-035X

Bandeng: Studi Kasus di Kecamatan Pasekan Kabupaten Indramayu. Buletin Ilmiah MARINA Sosial Ekonomi Kelautan Dan Perikanan, 1(1), 1-10. 